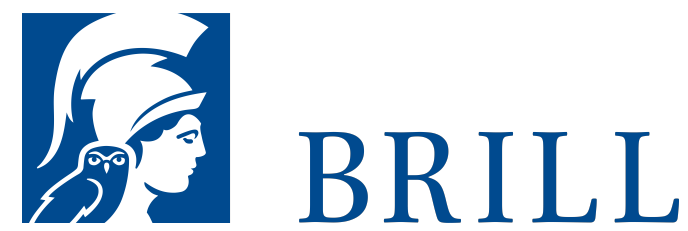

\title{
Temples, Religion and Politics in the Roman Republic
}

\section{Author: Orlin}

A study of the construction of new temples in the Roman Republic, a process which illuminates key features of both their political and religious systems. It offers an analysis of the relationship between the individual and the community, both human and divine, and their responsibilities toward one another.

The book examines in detail each of the three main stages in the construction of a new temple: the vow, the placing of a contract, and the dedication. Special attention is paid to the ability of a Roman magistrate to enter into building obligations on behalf of the state, and the role of the general's share of the spoils of war, his manubiae.

In contrast to previous studies, this work emphasizes the significant role played by the Roman Senate, and thus offers a new interpretation of the symbolic meaning of this process.

This publication has also been published in paperback, please click here for details.

\section{Readership}

All those interested in religious history or comparative religions, or the political, social, or cultural history of Rome, as well as political scientists.

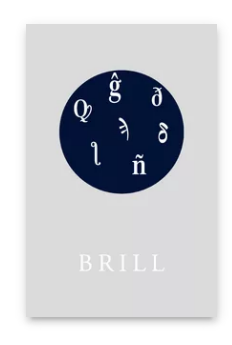

Pages: $\mathrm{x}, 227$ pp.

Language:

English

Subjects:

Ancient History,

Classical Studies

Publisher: Brill

Series:

Mnemosyne,

Supplements,

Volume: 164

Mnemosyne,

Supplements,

History and

Archaeology of

Classical

Antiquity,

Volume: 164

E-Book (PDF)

Released online:

16 Sep 2019

ISBN: 978-90-

04-32989-8

List price

USD \$16o.oo

Hardback

Publication date:

o1 Nov 1996

ISBN: 978-90-

04-10708-3

List price

USD. $\$ 151.00$ 
Eric M. Orlin, Ph.D. (1994), the Group in Ancient History and Mediterranean Archaeology at UC Berkeley, holds a joint appointment in the Historical Studies and Classical Studies programs at Bard College.

For more information see brill.com

\begin{abstract}
Order information: Order online at brill.com +44330 3330049 | customerservices@brill.com Submission information: brill.com/authors
\end{abstract}

Titles published by Brill | Fink, Brill | mentis or Brill | Schöningh: +49(o)71 5413279216 | brill@brocom.de 